\title{
Anabolic steroid-induced hypogonadism: a challenge for clinicians
}

\author{
Hyun Jun Park （Didtps://orcid.org/0000-0003-0566-9574
}

The history of the use of anabolic androgenic steroids (AAS) is older than we think. Dr. Brown-Seuard injected himself with "orchitic fluid" extracted from laboratory animals to improve his aging symptoms and reported improvement (Dotson and Brown, 2007). Since the introduction of oral methyltestosterone in 1935 , the use of synthetic androgen has started in earnest. Since the 1950 s, the structure of testosterone has been modified to increase the anabolic effect and minimize the androgenic effect, resulting in various AASs (Kicman, 2008). However, the use of AAS was not free from the characteristic sequelae of the use of androgen and resulted in an unfavorable side effect of anabolic steroid-induced hypogonadism (ASIH). ASIH is common as a cause of secondary hypogonadism in young men, especially because young men often use AAS (Coward et al., 2013; Jarow and Lipshultz, 1990). In young men, hypogonadism not only is a problem but also can cause a more serious problem such as infertility. Since AASs began to be used by Olympic athletes to improve performance in the 1950s, associated sports issues have emerged and now expanded to public health issues issues (Franke and Berendonk, 1997). The reason is that much more men actually use AAS indiscriminately. Among male gym attendees, the reported rate of using AAS ranges from $15 \%$ to $30 \%$ (Perry et al., 1992). In other words, as we often think or as coverage by mass media, AAS is not the problem of other worlds that only professional athletes use. The reality is that because of simple greed, four of five people use AAS to improve their appearance (Cohen et al., 2007; Ip et al., 2011; Parkinson and Evans, 2006; Perry et al., 1992). A serious problem is that clinicians, even endocrinologists and andrologists, do not have much information and knowledge about AAS. This is a reality from the lack of large well-designed studies on AAS and ASIH. AAS users get information about AAS from the Internet, blogs, social networking service, or self-named "expert nutritionists" who work in gyms. AAS is purchased through the Internet, and Internet suppliers sell bundled packages, including selective estrogen receptor modulators (SERMs), aromatase inhibitors, human chorionic gonadotropin (hCG), and phosphodiesterase-5 inhibitors (Cordaro et al., 2011; Cooper et al., 2013; Pirola et al., 2010). This means that not only the use of AAS but also the treatment of ASIH occurring after AAS is solved by AAS users themselves, not by the medical system. The pathophysiology of ASIH can be explained by the fact that AAS induces feedback suppression of the hypothalamic-pituitary-gonadal axis. Inhibition of pulsatile gonadotropin-releasing hormone release results in a decrease in luteinizing hormone and follicle-stimulating hormone (Rahnema et al., 2014). The main symptoms of ASIH are low endogenous testosterone levels, gynecomastia, testicular atrophy, sexual dysfunction, hepatic dysfunction, and alopecia. To restore ASIH, treatment strategies that increase the production of endogenous testosterone through treatment such as testosterone replacement, SERMs, and hCG should be done through accurate diagnosis and consultation with medical professionals.

In the sports athletic field, strict standards have been established and thorough doping tests have been conducted. However, no standard and regulation have been established for public use of AAS yet. To prevent the spread of the use of AAS in an indiscriminate way by noncompetitive athletes, it should be accepted as an important public health issue and public education should be strengthened through mass media. On the one hand, clinicians 
should have sufficient knowledge of AAS use, concepts of ASIH, and treatment strategies. Through counseling with AAS users, clinicians should understand why patients use AAS and what medical problems they are currently facing.

\section{CONFLICT OF INTEREST}

No potential conflict of interest relevant to this article was reported.

\section{REFERENCES}

Cohen J, Collins R, Darkes J, Gwartney D. A league of their own: demographics, motivations and patterns of use of 1,955 male adult nonmedical anabolic steroid users in the United States. J Int Soc Sports Nutr 2007;4:12.

Cooper ER, McGrath KC, Heather AK. In vitro androgen bioassays as a detection method for designer androgens. Sensors (Basel) 2013;13: 2148-2163.

Cordaro FG, Lombardo S, Cosentino M. Selling androgenic anabolic steroids by the pound: identification and analysis of popular websites on the Internet. Scand J Med Sci Sports 2011;21:e247-e259.

Coward RM, Rajanahally S, Kovac JR, Smith RP, Pastuszak AW, Lipshultz LI. Anabolic steroid induced hypogonadism in young men. J Urol 2013;190:2200-2205.

Dotson JL, Brown RT. The history of the development of anabolic-androgenic steroids. Pediatr Clin North Am 2007;54:761-769, xi.
Franke WW, Berendonk B. Hormonal doping and androgenization of athletes: a secret program of the German Democratic Republic government. Clin Chem 1997;43:1262-1279.

Ip EJ, Barnett MJ, Tenerowicz MJ, Perry PJ. The Anabolic 500 survey: characteristics of male users versus nonusers of anabolic-androgenic steroids for strength training. Pharmacotherapy 2011;31:757-766.

Jarow JP, Lipshultz LI. Anabolic steroid-induced hypogonadotropic hypogonadism. Am J Sports Med 1990;18:429-431.

Kicman AT. Pharmacology of anabolic steroids. Br J Pharmacol 2008;154: 502-521.

Parkinson AB, Evans NA. Anabolic androgenic steroids: a survey of 500 users. Med Sci Sports Exerc 2006;38:644-651.

Perry HM, Wright D, Littlepage BN. Dying to be big: a review of anabolic steroid use. Br J Sports Med 1992;26:259-261.

Pirola I, Cappelli C, Delbarba A, Scalvini T, Agosti B, Assanelli D, Bonetti A, Castellano M. Anabolic steroids purchased on the Internet as a cause of prolonged hypogonadotropic hypogonadism. Fertil Steril 2010;94:2331.e1-3.

Rahnema CD, Lipshultz LI, Crosnoe LE, Kovac JR, Kim ED. Anabolic steroid-induced hypogonadism: diagnosis and treatment. Fertil Steril 2014;101:1271-1279.

Department of Urology, Pusan National University School of Medicine, 179 Gudeok-ro, Seo-gu, Busan 49241, Korea E-mail: joon501@naver.com 